\title{
Implementation of Assistance for Victims of Domestic Violence
}

\author{
Nur Moh. Kasim¹, Sri Nanang Meiske Kamba ${ }^{2 *}$ \\ 1,2 Faculty of Law, Universitas Negeri Gorontalo, Indonesia \\ *Corresponding Author: S.N.M. Kamba, email: srinanangmeiskekamba@ung.ac.id
}

\begin{abstract}
This research aims to empirically analyses of implementation of counselling towards victims of domestic violence. The research method is descriptive qualitative. The population of this study were women (wives), who were victims of different types of domestic violence at Tabongo Timur Village. Based on the result, there were three pattern implementations of counselling that have been done at Tabonga Timur Village, firstly, providing direction/guidance; secondly, assisting domestic violence victims; and thirdly, establishing domestic violence clinic. The realization of the program of providing counselling of domestic victims at Tabonga Timur Village has not been optimal because the victims are afraid to report, limited fund allocation, inadequate facilities and infrastructure, and both characteristics of victims and factors of domestic violence are various.
\end{abstract}

Keywords: assistance; implementation; domestice violence

\section{How to cite:}

Kasim, N.H., \& Kamba, S.N.M (2019). 'Implementation of Assistance for Victims of Domestic Violence.' Indonesian Journal of Advocacy and Legal Services, 1(1), 147-156. DOI: 10.15294/ijals.v1i1.33801

\section{A. Introduction}

Human nature as a creature created by the classification of sexes between men and women, one with each other will be attracted to each other and then will unite themselves in marriage ties. Marriage as a forum that unites men and women who are always considered sacred and this condition can be understood because with the marriage, in addition to meeting biological 
needs, intended to be born offspring who are certainly expected to continue human life is sustainable. ${ }^{1}$

Domestic violence is not justified in terms of positive law and Islamic law. The essence of marriage is to form a happy and eternal family as regulated in Article 1 of Law No. 1 of 1974. In other words that every marriage can require a happy, harmonious family and can form a family sakinah mawaddah wa rahma. However, in reality that not all marriages go smoothly and in navigating the household ark. Every marriage can not fully feel happiness and love and love each other, but it causes discomfort, stress, or forced and hates each other. ${ }^{2}$

Triggers for the problem of domestic violence are very diverse, in the form of infidelity, economic problems, third party interference, differences in principles, and the problem of gambling or alcohol. Thus giving a negative impact on victims of violence in the household both physically, sexually, psychologically and / or neglect of the household, which provides a profound trauma impact on the victim. In addition, it gives the impact of the loss of confidence for the victim to get along and feel his life is threatened and intimidated.

In addition to the above reasons, observers of women's studies analyzing domestic violence are a serious problem, but so far they have not received a response from the community, partly because, first, domestic violence has a relatively closed (private) scope and is closely guarded by its privacy because it occurs within family. Second, domestic violence is often considered reasonable because of the belief that the husband as the leader and head of the household may treat his wife as he wishes. Third, domestic violence occurs in legal institutions, namely marriages. ${ }^{3}$

Ironically, some women who think that violence, both physical and nonphysical, is received is the result of their own mistakes. Women like this tend to blame themselves, so that if they accept violence from their husbands. ${ }^{4}$

The mistreatment and injustice suffered by women cannot be corrected by merely reforming the criminal justice system. The criminal justice system will be more effective in cracking down, preventing and responding to acts of violence against women, especially the problem of domestic

\footnotetext{
Moc. Isnaeni, 2016, Hukum Perkawinan Indonesia, PT. Refika Aditama, Bandung, hal. 9

2 Explanation of Article 1 of Law Number 1 of 1974 concerning Marriage

3 Asni, Menyorot Kekerasan Dalam Rumah Tangga (KDRT) Sebagai Penyebab Perceraian., MUSAWA, Journal for Gender Studies, Vol.6 No.IJuni 2014. Pusat Studi Gender Dan Anak IAIN Palu.

4 Moerti Hadiati Soeroso, 2012, Kekerasan dalam Rumah Tangga; dalam perspektif yuridis-viktimologis, Sinar Grafika, Jakarta Hal. 61
} 
violence. In addition to the criminal justice system that is concerned, victims in domestic violence need legal protection, physical and psychological health recovery, coaching. Women's safety and security must be a top priority for all parties. For perpetrators of domestic violence, law enforcement efforts are needed in the court process. So that the obstacles in guiding victims of domestic violence can be overcome by the government, as well as government and community cooperation in the implementation of providing assistance to victims of domestic violence in the village of East Tabongo can be realized.

Therefore, this paper discusses two main points, namely: (1) How is the implementation of giving guidance to victims of domestic violence in the village of east Tabongo? and (2) What are the obstacles faced in the implementation of providing guidance to victims due to domestic violence in the East Tabongo Village?

\section{B. Method}

This study regarding the pattern / form of providing guidance to victims of domestic violence as the right of victims of domestic violence to get protection and legal guarantees in handling violence that they experienced in the East Tabongo Village, is a type of empirical research using a qualitative descriptive approach with data analysis techniques sourced from data primary and secondary data. To achieve the above objective, interview techniques were used with respondents consisting of: Village Government and the community. The results of the interview will be analyzed qualitatively.

\section{Result and Discussion}

1. Patterns of Coaching and Assistance for Victims of Domestic Violence

\section{1) Giving Direction or Guidance}

From an interview (July 5, 2019) with Mr. Ahmad, the form of coaching conducted to address the problem of violence in the East Tabongo Village must first be reported from the victim, family or neighbor in case of violence, if it is proven true that the act of violence is then the village head will order the head of the hamlet and the head of the domestic violence complaint officer to go to the hamlet where the domestic violence case occurred. The head of the hamlet and the head of the board will go to the two warring 
parties. Both parties will be asked for information on the causes of the acts of violence in turn. ${ }^{5}$

Like the slap case experienced by Mrs. NI (victim) committed by Mr. IA (the perpetrator) in 2018. The cause is the husband asking permission from his wife to remarry. Mrs. NI did not accept the words of her husband and immediately issued a diatribe, so Mr IA immediately slapped him. NI's mother does not agree with her husband's remarriage because there are still many dependents that must be fulfilled by her husband. If her husband is given permission to remarry, then he will focus on paying attention to the needs of his second wife and will abandon him and his children. On the other hand, Mr. IA continues to be urged by his affair to marry and immediately divorce his first wife. ${ }^{6}$

From the above case, Mr. Ahmad argues that the problems of both parties must be resolved in a family way through deliberation. Therefore, both parties are given direction or guidance regarding the matter. Forms of direction or guidance are the form of a heart-to-heart approach so that solutions are found in problem solving. For example, the existence of mutual respect between husband and wife, reminding to mutual understanding, building a pure relationship (transparent) that is to maintain good relations so that marriages remain lasting and reminded to both parties how their struggle to get the blessing of parents to decide married.

In addition, both parties were advised (fostered) by religious leaders about the importance of marriage, the purpose of marriage is to form a sakinah family, mawddah warahmah, and provide education to both parties how to deal with the attitude of a husband or wife who at all times change due to stress or work pressure. As well as providing religious advice when a husband or wife is angry it's better to leave it alone, later after the emotions subside then talk slowly.

After Mr. Ahmad and the religious leaders gave guidance / advice to both parties, then all decisions were made to the two parties in trouble, whether the two parties would continue the matter to the law or they would be peaceful and consider the matter resolved. And in the end both parties chose to make peace and forgive each other. According to the results of interviews with Mr. Ahmad and Mr. Ismet (Village Head) this form of guidance (a heart-to-heart approach) has been successful and is still being used to resolve domestic violence problems and end peacefully.

5 Interview with Mr. Ahmad D Rajak (Chair of the Domestic Violence Complaints Stance Officer)

6 Interview with Victims of Domestic Violence 


\section{2) Assistance with Victims of Domestic Violence}

According to the results of an interview with Mr. Ismet (Village Head) said that in addition to the form of training approach, assistance was also needed by the cadres of domestic violence in each hamlet represented by (Hamlet Head) in each hamlet of Tabongo Timur Village. The head of the domestic violence complaint committee is assisted by the village head working with the community to provide education and reporting in the event of domestic violence in the community. The education carried out by Mr. Ahmad and his staff members took the form of conducting legal socialization in the handling of domestic violence. In addition, Mr. Ahmad assigns to each Head of Hamlet to provide assistance to victims of violence and provide protection from the threat of perpetrators of domestic violence. Forms of assistance by cadres of domestic violences prevention include:

a. Victim Assistance in collaboration with PKK

The assistance of victims of domestic violence will work together with community institutions, namely PKK (Family Welfare Development) in East Tabongo Village. The Chairperson of the Domestic Violence Complaints Committee will be assisted by the PKK along with cadres to conduct legal outreach in handling domestic violence and assist efforts to protect women, especially wives and children. According to an interview with Mr. Stevianus, the purpose of this socialization is to provide an understanding to the community of the negative effects of early marriage and increase public awareness about procedures for handling domestic violence in the village of East Tabongo. ${ }^{7}$

b. Assistance of victims to police institutions

According to an interview with Mr Ahmad, the form of assisting victims of domestic violence reached the legal channels (Polsek), if the two parties could not make peace through deliberations in the village. This assistance was implemented because many victims of domestic violence were lacking because of the most livelihoods of farmers.

c. Spiritual accompaniment

In addition to victim assistance which has been explained above, victim assistance can be done spiritually. This spiritual assistance is carried out by religious and community leaders in the East Tabongo Village. The purpose of this spiritual accompaniment is so that victims begin to draw closer to God, begin to arrange a new life again and forget all the problems that occur, can begin to regulate temperament to restrain their emotions, and

7 Interview with Mr. Stevianus Nggilu (Head of East Tabongo Village Administration) 
remind the purpose of marriage which is to form a family that is sure, mawadah and warahmah.

\section{d. Assistance of victims to the Domestic Violence Complaints Center}

Victims of domestic violence are generally afraid to report. Victims of domestic violence consider disgrace unnecessary to others. Therefore, domestic violence cases always increase every year. East Tabongo Village did not escape the problem. According to an interview with Mr. Ahmad said that those who always report when violence occurs is neighbors of victims of domestic violence. Therefore, Mr. Ismet instructed that each hamlet head must accompany the victim to be able to help report to the domestic violence complaints center in the village of East Tabongo, of course, assisted by the local community. In addition to accompanying the victims, the hamlet head also provides a place to conduct deliberations in resolving domestic violence problems before the problem is delegated to the village office.

3) Establishment of Domestic Violence Clinic

The clinic was formed in order to provide protection as well as legal assistance to victims of domestic violence, both to husbands, wives and children. This clinic will partner directly with related parties including; Gorontalo district women's and child protection institutions, the police, prosecutors, lawyers and local government.

\section{Obstacles in the Implementation of Coaching and Assistance for Victims of Domestic Violence}

Women who are often victims of domestic violence, this violence is usually done by their partners. Therefore, the issue of violence needs serious attention and treatment. The role of government and society is needed to deal with the problem. The service program provided by the government of East Tabongo Village is in the form of providing direction and assistance to victims of violence. However, in the implementation of providing guidance and assistance often the East Tabongo village government encountered obstacles. The obstacles encountered in the implementation of providing guidance as follows:

1) Victims Fear of Reporting

According to the results of interviews conducted with Mr. Ahmad said that victims (wives) of violence tend to be closed when the perpetrators (husbands) commit violence against him. The victim (wife) always hides the abusive treatment she receives from others. The perpetrators always threaten victims not to tell anyone, including their families. So, the victim chose silence for fear of adverse effects on the actions of his report. 
According to Mr. Ahmad, the neighbors who usually report when violence acts occur are neighbors, they feel they cannot bear to see the victim being abused by their husband. ${ }^{8}$

2) Limited Allocation of Funds

In connection with the lack of budget allocation for socialization activities in handling domestic violence carried out by the domestic violence complaints center. Companion funds for victims are considered insufficient let alone used for socialization activities. According to Mr. Ahmad's confession to carry out socialization activities are usually only done at the mosque before Friday prayers are held. This activity certainly has to get permission from the community about providing education about the importance of handling violence in the household. According to Mr. Ahmad, this is the best way to anticipate if the village does not have enough funds. In addition, the village government does not need to invite the community anymore because of course the community will come alone to perform Friday prayers. Therefore, the follow up for the implementation of the socialization was considered less than optimal.

3) Inadequate Facilities and Infrastructure

Inadequate facilities and infrastructure such as: domestic violence complaints centers are not available, rooms for socialization about education in handling domestic violence are inadequate, microphone and Laptop / LCD equipment are still borrowed from the village office, and places to resolve domestic violence problems are usually done in the hamlet head's house and if did not get a meeting point then proceed to the village office.

4) Characteristics of victims of domestic violence vary

In handling acts of domestic violence sometimes the management and village cadres (hamlet head) encounter problems. This is because domestic violence victims have various characteristics, for example victims who choose to remain silent when asked what causes violence, victims tend to be afraid to tell of the abusive treatment they received (passive / insecure attitude and fear in making decisions), and victims chose consider her economic needs rather than report her husband.

5) Factors that cause a variety of domestic violence

Domestic violence is a serious polemic in East Tabongo village. The perpetrators usually do not care about the consequences. Violence is usually experienced by women. According to Mr. Stevianus the number of victims of domestic violence in East Tabongo Village has increased. From year to year, there must be reports of acts of violence occurring in the community.

8 Interview with Mr. Ahmad D Rajak (Head of the Domestic Violence Complaints Committee) 
Violence is usually reported by neighbors or family members to the village office. From the last 3 years, there were 4 cases of domestic violence that entered the village office, not to mention violence that was not exposed and seemed to be covered up by victims of domestic violence. ${ }^{9}$

According to an interview with Mr. Ahmad the cause of the violence occurred was influenced by several factors including: economic, gambling, infidelity, and alcohol. Thus, it requires extensive knowledge and good strategies to deal with domestic violence problems.

\section{Conclusion}

Implementation of the provision of guidance in the village of East Tabongo for victims of domestic violence is carried out with 3 patterns in the form of the first, giving direction / advice carried out by the head of the domestic violence complaints committee, religious and community leaders, secondly assisting victims such as: assisting victims in collaboration with PKK, assisting victims to the police institution, spiritual assistance and assisting victims to the domestic violence center, the third was the formation of a domestic violence clinic. The obstacles encountered in the implementation of providing assistance to victims of domestic violence include: (1) victims are afraid to report, (2) limited funding allocation, (3) inadequate facilities and infrastructure, (4) the character of victims of domestic violence varies, and (5) various causes of domestic violence.

\section{E. Acknowledgments}

Thank to all faculty members of Faculty of Law, Universitas Negeri Gorontalo (UNG), Indonesia. Authors also would like to express a great thankfulness for all parties involved on the program.

\section{F. Declaration of Conflicting Interests}

The authors state that there is no potential conflict of interest in the research, authorship, and / or publication / publication of this article.

\section{G. Funding}

Program of the community services and research funded by Faculty of Law, Universitas Negeri Gorontalo (UNG), Indonesia.

9 Interview with Mr. Stevianus Nggilu (Head of East Tabongo Village Administration) 


\section{H. References}

Abdul, W. \& Irfan, M. (2011). Perlindungan Korban Kekerasan Seksual Advokasi atas Hak Asasi Manusia. Malang: PT Reflika Aditama.

Anwar, Y., \& Adang. (2016). Kriminologi. Bandung: Refika Aditama.

Asni, A.N. (2014). Menyorot Kekerasan Dalam Rumah Tangga (KDRT) Sebagai Penyebab Perceraian. MUSAWA: Journal for Gender Studies, 6(1), 504-527. Retrieved from http://jurnal.iainpalu.ac.id/index.php/musawa/article/view/126

Atmasasmita, R. (1985). Problema Kenakalan Anak-Anak/Remaja (Yuridis, Sosiologis, Kriminologi). Bandung: Armico.

Departemen Agama RI. (2006). Al-Qurran dan Terjemahannya, Cet.III. Depag RI: Bandung.

Fajar, M., \& Yulianto, A. (2013), Metode Penelitian Kriminologi. Jakarta: Kencana.

Gosita, A. (1985). Masalah Korban Kejahatan. Jakarta: Akademika Pressindo.

Gusliana, HB. (2010). Penyebab Terjadinya Kekerasan Dalam Rumah Tangga (KDRT) Yang Dilakukan Oleh Suami Terhadap Istri di Kota Pekanbaru". Jurnal Ilmu Hukum Universitas Riau, 1(1), 80-93. http://dx.doi.org/10.30652/jih.v1i01.482

Isnaeni, M. (2016). Hukum Perkawinan Indonesia. Bandung: PT. Refika Aditama.

Jayanthi, E.T. (2009). Faktor-Faktor Penyebab Terjadinya Kekerasan Dalam Rumah Tangga Pada Survivor yang Ditangani Oleh Lembaga Sahabat Perempuan Magelang. DIMENSIA: Jurnal Kajian Psikologi, 3(2), 33-50. $\quad$ Retrieved from https://journal.uny.ac.id/index.php/dimensia/article/view/3417/2902

Moleong, L. (1999). Metode Penelitian Kualitatif. Bandung: PT. Remaja Rosdakarya.

Puluhulawa, F.U. (2009). Perlindungan Hukum Terhadap Perempuan Sebagai Korban KDRT. Jurnal Legalitas, 2(1), 1-2. Retrieved from http://ejurnal.ung.ac.id/index.php/JL/article/view/629/578

Samadani, H.U.A. (2000). Kompetensi Pengadilan Agama terhadap Tindak Kekerasan dalam Rumah Tangga. Jakarta: Graha Ilmu.

Soeroso, M.H. (2012). Kekerasan Dalam Rumah Tangga dalam Perspektif Yuridis dan Viktimilogi. Jakarta: Sinar Grafika. 
Sugiono. (2008). Memahami Penelitian Kualitatif. Bandung: CV Alfabeta.

Syahruddin, N. (2013). Peneltian Hukum Normative Versus Penelitian Hukum Empiris. Makassar: PT Umitoha Ukhuwa Grafika.

\section{Laws and Regulations}

Law Number 23 of 2004 concerning the Elimination of Domestic Violence [Undang-undang Nomor 23 Tahun 2004 Tentang Penghapusan Kekerasan dalam Rumah Tangga]

Law Number 1 of 1974 concerning Marriage [Undang-undang Nomor 1 Tahun 1974 Tentang Perkawinan]

Copyrights (C) 2019 by Auhtor(s). This work is licensed under a Creative Commons Attribution-NonCommercial-ShareAlike 4.0 International License. All writings published in this journal are personal views of the authors and do not represent the views of this journal and the author's affiliated institutions. 